\title{
Sensory attributes and quality of meat in improved indigenous chicken fed on Prosopis juliflora pods in Kenya
}

\author{
Duncan Maina Wanjohi ${ }^{1,}{ }^{*}$, Anthony Macharia King' ori $^{2,{ }^{*}, \text { Ann Mumbi Wachira }}{ }^{3}$, Abdi Yakub \\ Guliye $^{2}$ and Peninah Njiraine Ngoda $^{4}$ \\ Animal Health and Industry Training Institute, P.O. Box 20300-1, Nyahururu, Kenya \\ ${ }^{2}$ Department of Animal Sciences, Egerton University, P.O. Box 536-20115, Egerton, Kenya \\ ${ }^{3}$ Poultry Unit-Non-Ruminant Research Institute (NRI), Kenya Agricultural and Livestock Research Organization, P.O. \\ Box 25-Naivasha, Kenya \\ ${ }^{4}$ Dairy and Food Science and Technology Department, Egerton University, Egerton-536, Kenya \\ ${ }^{*}$ Corresponding Authors Email: duncanwanjohi09@gmail.com: Tel: +254-720-614885
}

\begin{abstract}
Evaluation ofthe sensory and meat quality was performed on Kenya Agricultural and Livestock Research Organization (KALRO) improved chicken (KIC) fed on diets incorporated with ground Prosopis juliflora pods (GPJP. Breast and thigh samples were obtained from chicken fed on GPJPbased diets substituting whole diet at 0\% (PJP-0), $10 \%$ (PJP-10), 20\% (PJP-20) and $30 \%$ (PJP-30). Organoleptic characteristics were evaluated using questionnaires for attribute profiling and affective tests using trained and miniature consumer panels. Continuous anchored attribute scales and hedonic scale were used for sensory tests while meat quality was determined by Honikel method. Increasing the levels of GPJP had similar effect on Breast pH but PJP-20 had higher pH than cockerels offered PJP-0 and PJP-10 and pullets offered PJP-30. At $14^{\text {th }}$ day, pullet meat from PJP-0 had lower water holding capacity as compared to all other samples apart from cockerel samples from the same treatment. Pullets offered PJP-0 performed better in thigh and breast. In general acceptability (GA), $6.9 \%$ and $12.33 \%$ could be attributed to the effect of GPJP in thigh and breast in pullet and cockerel samples respectively. Results indicate that cockerels' meat had more favorable sensory effect than pullets' meat. Inclusion of $20 \%$ of GPJP in diet could be used to feed chicken while at the same time maintaining high quality meat desired by the consumers.
\end{abstract}

Key words: chicken, meat quality, Prosopis juliflora, sensory evaluation

\section{INTRODUCTION}

KALRO Improved chicken (KIC) is a recently introduced bird in Kenya rural areas as source of food and income. Indigenous chickens (IC) have an advantage of being more adapted to local stressful conditions (Kingori et al., 2010) than exotic chicken. They are widely preferred by consumers because of their lean meat, more protein content, taste and pigmentation (Kingori et al., 2010; Fanatico et al., 2007; Horst, 1991), fetches higher price in the market compared to exotic hybrid birds (Islam and Nishibori, 2009) and is preferred by health-conscious consumers due to its low levels of cholesterol and fat
(Jaturasitha et al., 2008).Despite high demand of IC products, the performance is low due to poor feeding among other challenges. Due to challenge in feed supply for the poultry sector, there has been introduction of unconventional feeds materials, such as Prosopis juliflora pods (Meseret et al., 2012), whose studies have proved it can be used to sustainably provide feed for the poultry subsector with remarkable performance (Al-Marzooqi et al., 2015). The feed offered to chicken affect carcass and meat quality either positively or negatively (Al-Marzooqi et al., 2015) and can affect 
Wanjohi et al., 133

different meat scores (Cheng-Yung et al., 2014). Consumers judge meat quality from its appearance, texture, juiciness, water holding capacity (WHC), firmness, tenderness, odor and flavor (Tougan et al., 2013). One of the factors that affect meat quality is closely related to decrease in the muscle pH (Le BihanDuval et al., 2008) after slaughter. Consumers usually prefer the breast and thigh muscles because they have the highest proportion of chicken carcass (Tougan et al., 2013).

The results of sensory analysis and meat quality, as a result of feeding a particular kind of diet, could allow producers to respond to preferences of consumers more easily (Saha et al., 2009; Liu et al., 2004). There is therefore need to determine whether addressing feed shortage in poultry subsector using Prosopis juliflora pods has an effect on improving meat quality and preference of IC by consumers which remains popular as compared to exotic breed (Al-Marzoogi et al., 2015). Hence, this research was aimed at determining the effect of GPJP on the sensory characteristics and meat qualities ( $\mathrm{pH}$ and water holding capacity) of growing indigenous chicken fed on GPJP based diets and therefore justify the use of the pods even to maintain IC quality products.

\section{MATERIALS AND METHOD}

\section{Study location}

This research study was carried out at the Dairy, Food Science and Technology Department of Egerton University, Kenya. It is located at latitude 0.23 'S and longitude $35^{\circ} 57^{\prime} \mathrm{E}, 2,238 \mathrm{~m}$ above sea level, with mean daily temperature of $21^{\circ} \mathrm{C}$. There is bimodal rainfall pattern (March to May and June to September) with a mean annual rainfall of $900-1,020 \mathrm{~mm}$ (Raude et al., 2006). The study was conducted between May and June 2015.

\section{Meat samples collection and preparation}

KIC were fed four types of diets formulations, with the control diet having 0\% (PJP-0, treatment 1), $10 \%$ (PJP10, treatment 2), 20\% (PJP-20, treatment 3) and $30 \%$ (PJP-30, treatment 4).

The meat samples of KIC slaughtered at 20 weeks of age from each diet were obtained from the breast and thigh parts. Good manufacturing practices were observed at all times. The meat not required for immediate analysis was kept under chilled $\left(4^{\circ} \mathrm{C}\right.$ or frozen $\left(-18^{\circ} \mathrm{C}\right)$ storage as appropriate.

\section{Meat quality traits ( $\mathrm{pH}$ and water holding capacity)}

Twenty-four hours after slaughter $\mathrm{pH}$ was measured using a pH meter calibrated using certified buffer $\mathrm{pH} 7.0$, $\mathrm{pH} 4.0$ and pH 9.2. Ten grams of the meat sample was cut from the breast muscle (pectoralis muscle) and drum stick muscle (Peroneus longus muscle) and blended with $50 \mathrm{mls}$ of distilled water (1:5 ratio) in a clean blender jar. $\mathrm{pH}$ measurement was taken at temperature between $20^{\circ} \mathrm{C}$ and $25^{\circ} \mathrm{C}$. Water holding capacity (WHC) was estimated by measuring drip loss of breast meat samples two days post slaughter after storing them (samples) at $4^{\circ} \mathrm{C}$ and then 7 and 14 days after slaughter using the bag method (Honikel, 1997).

\section{Questionnaire design and administration}

Questionnaires were used by panelists to evaluate the sensory characteristics of the various meat samples in terms of appearance, juiciness, taste, texture and overall acceptability. Attribute profiling was done using a scale $(10 \mathrm{~cm}$ long with anchored words such as too light and too soft, for the extreme left-hand side of the scale to too dark and too hard; at the extreme right and neither light nor dark, or neither soft nor hard at the center, the scale enabled continuous data to be obtained. The values were transformed as percentages for ease of use. A sevenpoint descriptive Hedonic Scale (7- Like extremely, 6Like very much, 5- Like moderately, 4- Neither like nor dislike, 3- Dislike moderately, 2- Dislike very much, 1Dislike extremely) was also used to determine general acceptability. A total of 30 panel members was constituted from lecturers, technicians and final year students in the Department of Dairy, Food Science and Technology at Egerton University, Kenya. The panel members were not given any information about the meat or the experimental treatments and procedures. Panelists were randomly presented samples from all treatment groups in duplicate in partitioned booths equipped with yellow bulb light. Between each sample, panelists were instructed to rinse their mouth with distilled water. A 15-minutes break period was allocated to the panelists halfway through the session.

\section{Meat preparation}

After thawing overnight at refrigerated temperature $\left(4^{\circ} \mathrm{C}\right)$, breast and thigh meat were cooked by boiling in $0.62 \%$ $\mathrm{NaCl}$ to an internal temperature of $75^{\circ} \mathrm{C}$ (at a 2:1 w eight ratio of solution to meat). Meat was skinned and cut into $1.9 \mathrm{~cm}$, bite-size cubes, wrapped in foil paper and placed in an oven at $22^{\circ} \mathrm{C}$ to keep warm. The tests were conducted at mid-morning (10-12noon) or mid-afternoon (3-4pm). 
134 Afr. J. Food Sci. Technol.

Table 1. Ultimate $\mathrm{pH}$ and water holding capacity (drip loss)

\begin{tabular}{|c|c|c|c|c|c|c|c|c|c|c|}
\hline \multirow[b]{2}{*}{$\begin{array}{l}\text { Parameters } \\
\text { pH }\end{array}$} & \multicolumn{8}{|c|}{ Treatments } & \multirow{2}{*}{ SEM } & \multirow{2}{*}{$\mathbf{P}$} \\
\hline & $\begin{array}{l}\text { PJP-0 } \\
\text { C }\end{array}$ & $\mathbf{P}$ & $\begin{array}{l}\text { PJP-10 } \\
\text { C }\end{array}$ & $\mathbf{P}$ & $\begin{array}{l}\text { PJP-20 } \\
\text { C }\end{array}$ & $\mathbf{P}$ & $\begin{array}{l}\text { PJP-30 } \\
\text { C }\end{array}$ & $\mathbf{P}$ & & \\
\hline Breast & $5.73^{\mathrm{D}}$ & $5.88^{\mathrm{ab}}$ & $5.72^{\mathrm{D}}$ & $5.81^{\mathrm{ab}}$ & $5.88^{\mathrm{ab}}$ & $5.97^{\mathrm{a}}$ & $5.95^{\mathrm{ab}}$ & $5.72^{\mathrm{b}}$ & 0.0413 & 0.032 \\
\hline $\begin{array}{l}\text { Drumstick } \\
\text { Drip Loss }\end{array}$ & 6.11 & 6.11 & 6.03 & 6.13 & 6.13 & 6.04 & 6.24 & 6.03 & 0.731 & 0.078 \\
\hline 2 days & $2.17^{\mathrm{ab}}$ & $2.23^{\mathrm{a}}$ & $2.11^{\mathrm{ab}}$ & $2.11^{\mathrm{ab}}$ & $2.09^{\mathrm{ab}}$ & $2.08^{\mathrm{ab}}$ & $2.03^{b}$ & $2.08^{\mathrm{ab}}$ & 0.342 & 0.016 \\
\hline 7 days & 4.19 & 4.18 & 4.14 & 4.15 & 4.09 & 4.13 & 4.11 & 4.61 & 0.156 & 0.064 \\
\hline 14 days & $6.70^{\mathrm{ab}}$ & $7.01^{\mathrm{a}}$ & $6.52^{\mathrm{bc}}$ & $6.58^{\mathrm{bc}}$ & $6.42^{\mathrm{bc}}$ & $6.62^{\mathrm{bc}}$ & $6.41^{c}$ & $6.48^{\mathrm{bc}}$ & 0.054 & 0.013 \\
\hline
\end{tabular}

${ }^{a b c}$ means with different superscripts differ significantly $(P<0.05)$ within a row; $P J P-0=$ diet containing $0 \%$ GPJP of the whole diet; PJP$10=$ diet containing 10\% GPJP of the whole diet; PJP-20= diet containing 30\% GPJP of the whole diet; PJP-30= diet containing $30 \%$ GPJP of the whole diet; GPJP = ground Prosopis juliflora pods; $\mathrm{C}=$ cockerel; $\mathrm{P}=$ pullet

\section{Statistical analysis}

Data obtained from the sensory evaluation of the various meat samples were analyzed using the Statistical Analysis Systems (SAS, 2002) using Complete Randomized Design (CRD) Model. Where the means were significant, they were separated using Tukey's Test (at $5 \%$ probability level). Kruskal Wallis $\mathrm{H}$ Chi-square test was used to analyze general acceptability hedonic scale data.

\section{RESULTS AND DISCUSSION}

\section{Ultimate $\mathrm{pH}(\mathrm{pHu})$ and water holding capacity (WHC)}

Pullet breast samples from PJP-30 had similar ultimate $\mathrm{pH}$ values as PJP-0 and PJP-10 but different from pullet breast in PJP-20(Table 1). All treatments had no effects on cockerel breast samples pHu values. Although samples from some treatments were out of the normal range of 5.8 to 5.9 as reported for broilers breast meat by Qiao et al., (2001). All values were within 5.7 and 6.1 beyond which of the both cockerel and pullet meat would show PSE syndrome and DFD syndrome at either extreme respectively.

All treatments had no effect on drumstick ultimate $\mathrm{pH}$ for both cockerels and pullets. These results are similar to the pHu values obtained by Al-Marzooqi et al., (2015) where inclusion of Prosopis juliflora pods had no effects of $\mathrm{pH}$. At two days after slaughter, pullet breast for PJP-0 lost more water as compared to cockerels' breast for the PJP-30. Drip loss was similar at 7 days after slaughter across all treatments. At 14 days after slaughter, pullet breast samples from PJP-0 lost more water than any other sample from both cockerels and pullets apart from cockerels receiving the same diet (PJP-0). This indicates that pullet breast lost more water at the same period as compared to the cockerel breast meat. This means that cockerel meat has better keeping quality compared to the pullet meat.

Water holding capacity (WHC) is one of the factors that consumers use to judge the quality of meat (Tougan et al., 2013). Although studies by Le Bihan-Duval et al., (2001; 1999) reported higher levels of heritability of 0.35 to 0.57 for $\mathrm{WHC}, \mathrm{pH}$ and meat color on broiler lines, some of the differences reported in the current study could therefore indicate the effect of Prosopis juliflora on meat qualities in improving the WHC of IC meat.

\section{Meat sensory evaluation}

The cockerel thigh samples results were similar in terms of appearance, juiciness, taste and texture with increase in the proportion of prosopis pods in cockerels' diets (Table 2). The results are in congruence with the finding of Meseret et al., (2012) where broiler meat had similar results when same levels of GPJP were included in the diet. These results are also similar to the ones reported by Al-Marzooqi et al., (2015) although15\% was the highest level of Prosopis juliflora pods used. This shows that increasing the proportion of Prosopis juliflora pods in the KIC diets has no effect on all consumer sensory attributes considered and up to $30 \%$ Prosopis juliflora pods can be used as cheaper poultry feed ingredient and meet the same cockerel's thigh meat attributes consumers have been used to. This could be an indication that nutrients in GPJP in all formulations were available to produce similar meat quality. Results indicate there was a difference in general acceptability (GA) in cockerels' thigh samples with diets accounting for a $6.9 \%$ difference on GA. PJP-30was less generally accepted at $8.56 \%$ and $11.07 \%$ when compared with PJP-0and PJP10 respectively. This could be due to the fact that appearance and juiciness in the pullet thigh, though no differences across all treatments were found, numerically, PJP-30 had a lower performance as compared toPJP-0 in influencing the panelist decision for general acceptability.

In pullet thigh meat, PJP-0 had higher values as compared to samples from all other treatments in terms of appearance, juiciness, taste and texture. These results are dissimilar to study by Meseret et al., (2012) who reported no effect of Prosopis juliflora pods at the same levels as the current study on broiler thigh meat. This 
Table 2. Meat sensory values and general acceptability results for different levels of Prosopis juliflora pods

\begin{tabular}{|c|c|c|c|c|c|c|c|c|c|c|c|}
\hline \multirow[b]{2}{*}{ Attribute } & \multicolumn{6}{|c|}{ Attribute profile } & \multicolumn{5}{|c|}{ Hedonic Scale } \\
\hline & PJP-0 & PJP-10 & $\begin{array}{l}\text { PJP- } \\
20\end{array}$ & PJP-30 & \multirow{2}{*}{ SEM } & \multirow{2}{*}{$\mathbf{P}$} & & \multicolumn{4}{|c|}{ Cockerel thigh } \\
\hline Cockerel thigh & & & & & & & & $x^{2}$ & df & $\mathbf{P}$ & $\%$ \\
\hline App. & 50.4 & 51.9 & 54.7 & 48.4 & 3.14 & .063 & GA & 8.22 & 119 & $.042^{*}$ & 6.91 \\
\hline Juiciness & 50.4 & 57.4 & 57.5 & 49.8 & 3.01 & .235 & Ovs30 & 5.05 & 59 & $.025^{\star}$ & 8.56 \\
\hline $\begin{array}{l}\text { Taste } \\
\text { Texture }\end{array}$ & $\begin{array}{l}54.5 \\
56.2\end{array}$ & $\begin{array}{l}62.2 \\
57.9 \\
\end{array}$ & $\begin{array}{l}58.3 \\
64.8\end{array}$ & $\begin{array}{l}59.8 \\
59.2\end{array}$ & $\begin{array}{l}3.15 \\
3.51 \\
\end{array}$ & $\begin{array}{l}.074 \\
.251\end{array}$ & 10vs30 & 6.52 & 59 & $.011^{*}$ & 11.1 \\
\hline \multirow{2}{*}{ Pullet thigh } & & & & & & & & \multicolumn{3}{|c|}{ Pullet thigh } & \\
\hline & & & & & & & & $x^{2}$ & df & $\mathbf{P}$ & $\%$ \\
\hline App. & $85.6^{\mathrm{a}}$ & $65.8^{D}$ & $71.5^{b}$ & $64.3^{\mathrm{D}}$ & 3.14 & .026 & GA & 1.22 & 119 & .709 & 1.02 \\
\hline Juiciness & $73.3^{\mathrm{a}}$ & $46.2^{\mathrm{b}}$ & $55.50^{\mathrm{b}}$ & $48.9^{b}$ & 4.02 & .005 & & & & & \\
\hline Taste & $82.8^{a}$ & $62.4^{\mathrm{D}}$ & $62.7^{\mathrm{b}}$ & $59.3^{\mathrm{b}}$ & 3.56 & .009 & & & & & \\
\hline Texture & $64.3^{\mathrm{ab}}$ & $57.5^{\mathrm{b}}$ & $68.4^{a}$ & $66.8^{\mathrm{ab}}$ & 2.91 & .035 & & & & & \\
\hline \multirow{2}{*}{ Cockerel breast } & & & & & & & & \multicolumn{3}{|c|}{ Cockerel breast } & \\
\hline & & & & & & & & $x^{2}$ & df & $\mathbf{P}$ & $\%$ \\
\hline App. & 59.4 & 59.8 & 63.7 & 67.6 & 3.29 & .743 & GA & 1.90 & 119 & .593 & 1.59 \\
\hline Juiciness & 41.1 & 42.3 & 43.5 & 45.4 & 3.99 & .245 & & & & & \\
\hline Taste & 52.9 & 52.8 & 56.4 & 57.9 & 4.24 & .266 & & & & & \\
\hline Texture & 47.9 & 52.4 & 52.7 & 55.4 & 4.26 & .871 & & & & & \\
\hline \multirow{2}{*}{ Pullet breast } & & & & & & & & \multicolumn{2}{|c|}{ Pullet breast } & & \\
\hline & & & & & & & & $x^{2}$ & df & $\mathbf{P}$ & $\%$ \\
\hline App. & $79.6^{a}$ & $50.8^{b}$ & $50.4^{b}$ & $50.6^{b}$ & 3.11 & .002 & GA & 14.7 & 119 & $.002^{*}$ & 12.3 \\
\hline Juiciness & $65.3^{\mathrm{a}}$ & $56.7^{\mathrm{ab}}$ & $48.2^{\mathrm{b}}$ & $56.9^{\mathrm{ab}}$ & 3.03 & 0.05 & Ovs10 & 10.5 & 59 & $.001^{*}$ & 17.7 \\
\hline Taste & $72.7^{\mathrm{a}}$ & $60.1^{\mathrm{ab}}$ & $62.7^{\mathrm{ab}}$ & $58.3^{\mathrm{b}}$ & 3.03 & .009 & $10 v s 20$ & 11.9 & 59 & $.001^{\star}$ & 20.4 \\
\hline Texture & 63.6 & 61.9 & 56.7 & 56.9 & 3.46 & .037 & 10vs30 & 7.97 & 59 & $.005^{\star}$ & 13.5 \\
\hline
\end{tabular}

${ }^{\mathrm{ab}}$ means with different superscripts differ significantly $(\mathrm{P}<0.05)$ within a rowPJP-0 $=$ diet containing $0 \%$ GPJP of the whole diet; PJP-10= diet containing $10 \%$ GPJP of the whole diet; PJP-20= diet containing $30 \%$ GPJP of the whole diet; PJP-30= diet containing $30 \%$ GPJP of the whole diet; GPJP = ground Prosopis juliflora pods; GA = general acceptability; $\mathrm{C}=$ cockerel; $\mathrm{P}=$ pullet; * $\mathrm{p}<0.05$;

$\%=$ percentage of effect contributed by diets; $\mathrm{App}=$ appearance; $\mathrm{X}^{2}=$ chi square

indicates that as the percentage of GPJP is increased, consumers tend to have less preference in terms of appearance, juiciness taste, and texture. This can be attributed to the fact that the nutrients in the diets were not readily available to the pullets probably because they consumed less feed and also because the consumed feed had high amount of CF and antinutritive factors resulting from increasing percentage of Prosopis juliflora pods. Also, as the levels of GPJP increased, lower values of $\mathrm{pH}$ were observed (Table 1) whose effect on meat color, and dryness is not in congruence to what was reported in broiler meat (Alnahhas et al., 2014) an indication that the variation could be as a result of other factors, like the levels of GPJP. For the appearance, the higher levels of Prosopis juliflora could cause a higher percentage of red fibers in the muscles over white fibers resulting to darker meat as compared to lower levels of GPJP inclusion. Also, this may be due to the fact that pullets' thigh had a lower ultimate $\mathrm{pH}$ that reduced the water holding capacity and consequently affected the meat characteristics desired by the consumers. Although the panelist rated PJP-0 as having better performance in terms of appearance juiciness and taste, there was no difference in the 
136 Afr. J. Food Sci. Technol.

GA of the pullet thigh. This could be attributed to tenderness which was similar in both PJP-0 and PJP-10.

Increasing the levels of prosopis pods had similar effect on affect appearance, juiciness, taste and texture in breast meat from cockerels. The results for breast were similar to thigh meat recorded in the current study where the panelist could not detect any difference in attributes from the different levels of GPJP which is in agreement with the findings of Al-Marzooqi et al., (2015) and Meseret et al., (2012). The $\mathrm{pH}$ values are also within the range (5.7 and 6.1) reported in broiler breast meat by Alnahhas et al., (2014) and therefore might be the reason for similarity in appearance, juiciness, taste and texture since the $\mathrm{pH}$ were similar and could not cause any difference in the meat qualities. The results for general acceptability were similar in cockerels' breast meat.

In pullet breasts, PJP-0 had lighter appearance than samples from all other treatments. This shows that higher levels of GPJP made the pullet carcass to appear darker. This indicates that as the level of Prosopis juliflora pods increased it had an effect of making the meat darker. Breast meat has very low content of myoglobin and the darkening of meat as GPJP levels increased might be due to the nutrients available in the formulations, slaughtering environmental and other stresses the birds were subjected to at the time of slaughter rather that due to myoglobin content. The same treatment had juicier breast meat than PJP-20 indicating that higher levels of Prosopis juliflora pods made the meat less juicy. The taste of the breast meat was similar in the first three treatments, with PJP-0being tastier than the highest level of GPJP (PJP-30). These findings on the taste were similar to results reported by Meseret et al., (2012) in broilers pointing to the fact that nutrients required to enhance the taste, such as fatty acid, are not readily available at $30 \%$ (PJP-30) of Prosopis juliflora pods inclusion level. None of the treatments had effect on softness of pullet breast meat which is similar to findings of Meseret et al., (2012). This points out to the fact that cross linkages in collagen formation, which is important in tenderness of meat, (Tougan et al., 2013), is affected the same way at all levels of GPJP inclusion. Results for pullets' breast indicate that the effect of diets caused positive effect difference in general acceptability with $12.33 \%$ of the difference being attributed to the diets. Specifically, pairwise comparison of results between PJP-0and PJP10, PJP-10 and PJP-20 and PJP-10 and PJP-30 indicate that the first pair in each pairwise comparison had higher values for general acceptability of $17.73 \%, 20.39 \%$ and $13.50 \%$ respectively. The trend observed is almost similar to what is observed in appearance and taste whereby, as the level of GPJP was increased, the pullet's breast meat became darker and less tasty as seen in numerical value changes across the treatments. This indicates the nutrients available for the taste are directly related to the amount of Prosopis juliflora pods in the diet and increasing the prosopis in the diet had negative effect on color and taste.

\section{CONCLUSION}

The study shows Prosopis juliflora pods can be used to feed chicken to produce quality chicken products at a lower cost. Cockerels perform better in meat quality and can be fed with up to $20 \%$ Prosopis juliflora pods. Most of the sensory evaluation results are inclined centrally, an indication that Prosopis juliflora pods give quite similar results as the conventional diets. There should be sensitization on the use of Prosopis juliflora pods in compounding chicken feeds to both the feed millers and communities in ASAL areas as a means of tackling the challenge of feed shortage and cost and also produce good quality products.

\section{ACKNOWLEDGMENT}

The research was supported by Poultry Unit-NonRuminant Research Unit of Kenya Agricultural Livestock Research Organization (KALRO) in providing the chicken for the experiments, Egerton university, through Dairy and Food Science and Technology Department for providing sensory evaluation panel and facilities and Animal Sciences Department for Laboratory services. The assistance of Dr. Kiplangat Ngeno in data analysis is appreciated.

\section{REFERENCES}

Al-Marzoogi W, Al-Kharousi K, Kadim I T, Mahgoub O, Zekri S, AlMaqbaly R, Al-Busaidi M (2015). Effects of feeding Prosopis juliflora pods with and without exogenous enzyme on performance, meat quality and health of broiler chickens. Int. J. Poult. Sci. 14 (2): 76-88.

Alnahhas N, Berri C, Boulay M, Baéza E, Jégo Y, Baumard Y, Chabault M, Le Bihan-Duval E (2014). Selecting broiler chickens for ultimate $\mathrm{pH}$ of breast muscle: Analysis of divergent selection experiment and phenotypic consequences on meat quality, growth, and body composition traits. J.Anim. Sci. 92:3816-3824.

Cheng-Yung L, Hsiao-Yun K, Tien-Chun W (2014). Effect of free-range rearing on meat composition, physical properties and sensory evaluation in Taiwan game hens. Asian-Australas J. Anim. Sci. 27(6): 880-885.

Fanatico A C, Pillai P. B, Emmert J L, Gbur E E, Meullenet J F, Owens C M (2007). Sensory attributes of slow- and fast-growing chicken genotypes raised indoors or with outdoor access. Poult.Sci86:24412449 .

Honikel K O (1997). Water holding capacity. The bag method. Institute for Learning and Research Technology, University of Bristol, United Kingdom.

Horst P (1991). Native fowl as a reservoir for genomes and major genes with direct and indirect effects on the adaptability and their potential for tropically oriented breeding plans-a review. Anim. Res. Dev.33: 63-79.

Islam M A, Nishibori M (2009). Indigenous naked neck chicken: a valuable genetic resource for Bangladesh. Worlds. Poult. Sci. J., 65: $125-138$. 
Jaturasitha S, Kayan A, Wicke M (2008). Carcass and meat characteristics of male chickens between Thai indigenous compared with improved layer breeds and their crossbred. Arch. Tierz., Dummerstorf, 51(3): 283-294

Kingori A M, Wachira A M, Tuitoek J K (2010). Indigenous chicken production in Kenya: A review. Int. J. Poult. Sci. 9 (4): 309-316.

Le Bihan-Duval E, Berri C, Baéza E, Millet N, Beaumont C (2001). Estimation of the genetic parameters of meat characteristics and of their genetic correlations with growth and body composition in an experimental broiler line. Poult.Sci.80: 839-843.

Le Bihan-Duval E, Debut M, Berri C M, Sellier N, Santé-Lhoutellier V, Jégo Y, Beaumont C (2008). Chicken meat quality: genetic variability and relationship with growth and muscle characteristics BMC Genet.9:53.

Le Bihan-Duval E, Millet N, Rémignon H (1999). Broiler meat quality: effect of selection for increased carcass quality and estimates of genetic parameters. Poult.Sci.78: 822-826.

Liu Y, Lyon B G, Windham W R, Lyon C E, Savage E M (2004). Principal component analysis of physical, color and sensory characteristics of chicken breasts deboned at two, four, six and twenty-four hours postmortem. Poult.Sci. 83:101-108.

Meseret G, Mengistu U, Getachew A (2012). Ground Prosopis juliflora Pods as feed ingredient in poultry diet: Effects on nutrient intake, muscle fatty acid composition sensory quality and hematology of broilers. Pak. J. Nutri. 11 (11): 1014-1022.
Qiao M, Fletcher D L, Smith D P, Northcutt J K (2001). The effect of broiler breast meat color on $\mathrm{pH}$, moisture, water holding capacity, and emulsification capacity. Poult.Sci.80, 676-680.

Raude J M (2006). Determination of surface runoff and soil loss under varying rainfall intensity in selected land use practices in River Njoro catchment in Kenya. (MSc. Thesis Egerton University)

Saha A, Perumall A V, Lee Y, Meullenet J F, Owens C M (2009). Tenderness, moistness, and flavor of pre- and post-rigor marinated broiler breast fillets evaluated by consumer sensory panel. In Poult. Sci., 88:1250-1256.

SAS (2002). Statistical Analysis Systems Institute/STAT: User's Guide. Release (6.03 Edition). Cary, NC, United States of America.

Tougan P U, Dahouda M, Salifou C F A, Ahounou S G A, Kpodekon M T Mensah G A, André Thewis A, Karim I Y A (2013). Conversion of chicken muscle to meat and factors affecting chicken meat quality: a review. Int. J. Agron. Agric. Res. 3(8):1-20. 